\title{
Responding to anti-social behaviour: Analysis, interventions and the transfer of knowledge
}

\author{
Karen Bullock \\ Department of Sociology, University of Surrey, Guildford, GU2 7XH, UK. \\ E-mail: k.bullock@surrey.ac.uk
}

\begin{abstract}
This article examines contemporary responses to anti-social behaviour (ASB) in England and Wales. Drawing on empirical evidence, it examines how ASB problems are understood and prioritised by practitioners; the nature of the interventions developed and implemented to address problems; and the ways in which outcomes are evaluated. The article points to how systematic analysis of ASB problems is unusual and responses are usually reactive; there has been a focus on enforcement interventions rather than on the development of broader solutions to problems; and evaluation of outcomes is weak. These findings are discussed in relation to the development of the ASB agenda in England and Wales. Implications for solving problems are discussed.

Crime Prevention and Community Safety (2011) 13, 1-15.

doi: $10.1057 /$ cpcs.2010.19
\end{abstract}

Keywords: anti-social behaviour; analysis; enforcement; transfer of knowledge

\section{Introduction}

This article examines approaches to tackling anti-social behaviour (ASB). Drawing on case studies of 'good practice', it examines how ASB problems come to the attention of the authorities; the tools and techniques used to tackle them; and how outcomes are evaluated. It critically considers how the development of ASB policy in the United Kingdom has shaped local responses, and discusses implications for practice.

\section{Background}

Tackling ASB has been a priority for successive UK governments. High profile campaigns aimed at improving the local response to ASB have been implemented. ${ }^{1}$ Legislation has been passed, ${ }^{2}$ tools and techniques have been developed and guidance for practitioners issued. ${ }^{3}$ However, this is not a uniquely British issue. In developing tools to tackle ASB, the UK government has looked to the United States for inspiration, and in turn other countries - notably Australia - have watched the UK response with interest (Burney, 2005; Millie, 2009).

The development of ASB policy in the United Kingdom has reflected 'notions of self-regulation, active citizenship and communitarian-informed rights and responsibilities' (Nixon and Hunter, 2009, p.119), and has been linked to broader concerns to revive civil society (Burney, 2009). The rhetoric of the New Labour government's ASB campaigns 'Together' and 'Respect', which ran between 2004 and 2008, focused on building strong families, stable communities and empowering individuals and communities to act together to prevent ASB (Respect, 2006). The 'Youth Taskforce', which replaced Together and Respect, similarly stressed on 
building cohesive and sustainable communities, increasing young people's engagement with positive activities and partnership working (Youth Taskforce, 2008).

In practice, the ASB agenda has concentrated on the development of new (or extended) powers to enforce the criminal and / or civil law against perpetrators of ASB (or against 'proxies', such as carers). ${ }^{4}$ In this context, the family, with a focus on 'dysfunctional families' and 'bad parents', has been an important site of regulation (Nixon and Hunter, 2009) and tenants of social housing have been a primary focus of ASB interventions (Burney, 2005).

These developments have been the springboard for much critical comment. Debates have focused on how ASB powers blur criminal and civil proceedings; the implications for human rights and social control; and, the impact on families who are already socially disadvantaged or otherwise vulnerable (for example, Ashworth et al, 1998; Brown, 2004; Burney, 2005; Squires and Stephen, 2005; Squires, 2006; Nixon and Hunter, 2009). There have also been practical problems in delivering the ASB policy locally. The original take-up of the new powers was slow (Campbell, 2002), has subsequently been patchy (NAO, 2006) and administrative failures have undermined the actions taken by local councils in dealing with ASB problems (LGO, 2005). Practitioners have also raised concerns about the government's approach. These include: failure to take account of practitioners' views in developing policy; the emphasis on enforcement powers, rather than the development of other, more supportive, ways of tackling problems; and, a lack of long-term planning (Cooper et $a l, 2009)$. There has additionally been criticism of the lack of commitment to evaluation of the impact of new tools and powers (Squires and Stephens, 2005; Hodgkinson and Tilley, 2007; Prior, 2009).

\section{This Article}

This article seeks to contribute to what we know about how practitioners tackle ASB in England and Wales. It is concerned especially to explore the role of 'problem solving' or the 'preventative process' in contemporary approaches to tackling ASB. Accordingly, the article explores the role that data and analysis play in understanding and prioritising problems, the types of interventions selected to tackle ASB, how those measures were implemented and the nature of the evaluation of outcomes.

In doing so, it draws on an analysis of $46^{5}$ case studies of local responses to ASB. These case studies were submitted to a Home Office website by practitioners who were invited to describe their experiences (positive and negative) of tackling ASB. The stated aim of doing so being 'to share good practice and examples of differing approaches to tackling a problem'. ${ }^{6}$ In the name of learning from experience, the website invited practitioners to submit examples where interventions had not worked well, although, as we will see, these were rare. In this sense, the case studies formed a knowledge base from which other practitioners could learn and, although the website did not use the term, the information is presented in the format of the ' 5 Is' knowledge management framework that aims to help practitioners select interventions and to replicate practice (see Ekblom, 2010). The emphasis of this article is on illuminating aspects of practice and the implications for the preventative process. For that reason, the case studies were coded and analysed quantitatively to examine the following themes: ${ }^{7}$

1. The nature of ASB problems: how was ASB identified; what data sources were used to do so; which problem were being addressed; and, what were the characteristics of that problem? 
2. The development of responses to ASB: which powers and tools were being used to address problems; how were they implemented; and, which agencies were involved in addressing the problem?

3. Evaluation and the transfer of knowledge: what impact did the interventions have on the problem; were interventions successful in achieving their aims;

and, what evaluation design and sources of data were used to assess impact?

The following sections describe the results. Subsequent sections discuss the findings in relation to wider literature and the development of ASB policy, and set out implications for practice.

\section{Identifying, Understanding and Responding to ASB The nature of ASB}

The range of behaviours defined as 'anti-social' is potentially wide ranging. ASB is generally taken to straddle the 'sub-criminal' and minor criminal behaviour divide, but excludes serious offending (Millie, 2006, p.2). The case studies were attempting to tackle a wide range of criminal and non-criminal behaviours from the relatively minor to the rather serious. Each case study was tackling, on average, three different problems with a range spanning $1-10$. Problems included litter, noise, young people hanging around; riding bikes on footpaths; drugs (and the various impacts of drug use including evidence of drug detritus), criminal damage, shoplifting, vehicle crime, burglary, fraud, threats (including threats to kill), assault, sexual violence and kidnap. Reflecting diversity, typologies of ASB have been developed (see, for example, Harradine et al, 2004; Millie et al, 2005). Drawing on these and expanding them to account for the behaviours that the cases were tackling in practice, the cases were classified into the typology set out in Table 1.

The category 'misuse of public places' incorporated cases focused on, for example, begging and rough sleeping, public drinking and prostitution. The category 'youths hanging around' encapsulates the classic ASB stereotype of young people congregating in certain places. Doing so may intimidate some, or otherwise create nuisance, but is not necessarily directed at a particular individual. The category 'interpersonal' was used to represent cases where ASB was targeted specifically at a person or group of people. The category was split into two: cases where the problem was within a family (for example, domestic violence) and cases where there was no familial relationship between the victim and offender. Eight cases focused on crime problems. That category was also split into two to demonstrate that some cases focused on the nuisance caused by crime (for example, a crack house resulting in noise and drug detritus), whereas others were concerned specifically with crime (for example, shoplifting). A small number of cases focused on ASB problems that affected the environment (for example, graffiti or litter) and nuisance premises (for example, noisy bars).

Table 1 : Classification of problem type

\begin{tabular}{|l|l|}
\hline Problem type & N \\
\hline Misuse of public places & 10 \\
\hline Youths 'hanging around' & 10 \\
\hline Interpersonal & 13 \\
\hline Familial & 3 \\
\hline
\end{tabular}




\begin{tabular}{|l|l|}
\hline Non-familial & 10 \\
\hline Crime & 8 \\
\hline Crime & 4 \\
\hline Crime resulting in nuisance & 4 \\
\hline Environmental & 3 \\
\hline Nuisance premises & 2 \\
\hline Other & 1 \\
\hline & \\
Total & 47 \\
\hline
\end{tabular}

\section{Identifying and understanding ASB}

Analysis of the cases suggested that action against problems identified as ASB tends to be a reactive response to specific complaints, rather than a proactive one based on broad understanding of local problems. Indeed, overall there was little evidence of systematic analysis of the problems before developing and implementing responses only 7 out of 46 cases demonstrated evidence of systematic analysis of the nature of the problem.

In the cases where it was clear how a problem had come to the attention of the authorities (27 cases), it was usually prioritised as a result of complaints from residents (22). In only a small number of cases, action commenced proactively following scanning and analysis of crime/ASB prevalence or perception data. The following case illustrates the distinction between a proactive and reactive response to ASB and notes implications. ${ }^{8}$ The Bransty Estate is in Whitehaven, Cumbria, in the North West of England. The housing is mainly owned by social landlords. Routine scanning and analysis of ASB identified increases in the number of instances being recorded. Detailed analysis identified a specific problem of a small number of young people repeatedly targeting the same addresses on the estate with harassment, criminal damage and verbal abuse. Actions followed on the basis of these analyses. The chances are that this problem would not have been prioritised in this way without routine scanning and detailed analysis of data sources.

\section{Responses to ASB}

Reflecting the multifaceted nature of the problems, the responses were often multiagency involving, on average, four agencies. Nearly all involved the police. The local (or city) councils and housing associations and departments were also commonly represented. However, there was a huge range of organisations - public, private and third sector - involved in these case studies including solicitors, residents associations, the fire service, trading standards, schools, private landlords, drug services and alcohol services and even the RSPCA.

Analysis of the powers and tools utilised in the case studies revealed a wide mix of responses. On average, each case study used three distinct powers or interventions. Although many cases clearly did make use of diversionary and other supportive interventions, reflecting the concerns highlighted in the introduction, it is evident that there has been a great deal of emphasis on enforcement interventions. Table 2 reveals the wide range of interventions being used to tackle the identified ASB/crime problems.

Table 2 : Responding to ASB

\begin{tabular}{|l|l|l|}
\hline 'Traditional' law & ASB legislation and & Tenancy enforcement (19)
\end{tabular}




\begin{tabular}{|c|c|c|}
\hline $\begin{array}{l}\text { enforcement (24) } \\
\text { Enforcement of the } \\
\text { criminal law (14) High } \\
\text { Visibility Policing (5) } \\
\text { Confiscating cars (3) } \\
\text { Police visits (1) Disrupting } \\
\text { drug markets (1) }\end{array}$ & $\begin{array}{l}\text { powers (44) } \\
\text { ASBO (14) ABC (9) } \\
\text { Closure of premises (8) } \\
\text { Dispersal area (6) Curfew } \\
\text { (1) Penalty notice for } \\
\text { disorder (2) Fireworks (2) } \\
\text { Noise abatement order (1) } \\
\text { Other (1) }\end{array}$ & $\begin{array}{l}\text { Tenancy enforcement (10) } \\
\text { Injunction (5) Warnings } \\
\text { (4) }\end{array}$ \\
\hline $\begin{array}{l}\text { Support / diversion (30) } \\
\text { Diversion (12) Drug and } \\
\text { alcohol interventions (4) } \\
\text { education support (4) } \\
\text { Social work/Youth } \\
\text { Inclusion Programme } \\
\text { (YIP)/Youth Offending } \\
\text { Team (YOT) (3) Outreach } \\
\text { (3) Parent support (2) Fire } \\
\text { safety course (1) Tenancy } \\
\text { support (1) }\end{array}$ & $\begin{array}{l}\text { Environmental / SCP (10) } \\
\text { Environmental } \\
\text { improvements (8) } \\
\text { Situational Crime } \\
\text { Prevention (1) Product } \\
\text { design (1) }\end{array}$ & $\begin{array}{l}\text { Other (14) Media } \\
\text { campaign (3) Collecting } \\
\text { evidence (2) Publicity (3) } \\
\text { Problem-solving meetings } \\
\text { (3) Community initiatives } \\
\text { (2) Community } \\
\text { punishment order (1) }\end{array}$ \\
\hline
\end{tabular}

$n=141$.

A third of cases centred on young people. Again, responses to problems caused by children were wide ranging, and many incorporated diversionary and supportive interventions (Table 3). As we have seen, after 2007 the Respect agenda (led by the Home Office) evolved into the Youth Taskforce (led by the then Department for Children, Schools and Families). This placed the responses to ASB more firmly within the 'Every Child Matters' agenda, which in turn aimed more specifically to combine enforcement with support and prevention (DCSF, 2008). Even so, the enforcement agenda is clear.

Table 3 : Responses to ASB by young people

\begin{tabular}{|l|l|l|}
\hline $\begin{array}{l}\text { Traditional law } \\
\text { enforcement responses } \\
\text { (10) }\end{array}$ & $\begin{array}{l}\text { Anti-social behaviour } \\
\text { legislation responses (19) } \\
\text { Law enforcement (5) High } \\
\text { visibility patrol (2) Police } \\
\text { visit (2) Car removal } \\
\text { scheme (1) }\end{array}$ & $\begin{array}{l}\text { Enforcement of tenancy (7) } \\
\text { Warning (5) Eviction (1) } \\
\text { Other injunction (1) }\end{array}$ \\
\hline $\begin{array}{l}\text { Support and diversion (23) } \\
\text { Diversion (10) Parent } \\
\text { support (1) YOT, YIP, } \\
\text { social work (3) Outreach } \\
\text { or mentoring (2) Education } \\
\text { support (3) Drug/alcohol } \\
\text { interventions (2) Tenancy } \\
\text { support (1) Fire safety } \\
\text { course (1) }\end{array}$ & $\begin{array}{l}\text { Environmental or } \\
\text { situational (3) } \\
\text { Environmental } \\
\text { improvements (2) CCTV } \\
\text { (1) }\end{array}$ & $\begin{array}{l}\text { Other (3) } \\
\text { Communication with } \\
\text { residents (1) Case } \\
\text { conference / problem- } \\
\text { solving meetings (2) }\end{array}$ \\
\hline$N=65$. & \\
\hline
\end{tabular}


ASB interventions are disproportionately applied against those who reside in the social rented sector of the housing market (Brown, 2004; Burney, 2005). Certainly, over-representation of social rented housing tenants was evident in these case studies (17 out of 47). ${ }^{9}$ The regulatory mechanisms of social housing are used to apply pressure on tenants to control both their own behaviour and the behaviour of others (children or visiting friends and family) (Burney, 2005; Squires, 2006). Indeed, Table 3 notes the tenancy enforcement proceedings brought where the perpetrator was a child. The risk of losing the home is a significant threat for tenants of social housing, and rather than face eviction families may choose to accept a transfer from the area (Brown, 2004). Three cases noted that the tenants had voluntarily moved from their home to avoid the threat of eviction.

Some cases were further complicated because the perpetrator was also abusing the tenant. To illustrate, in one complicated and long-running case a son abused (mentally, physically and sexually) his elderly mother who resided in sheltered accommodation. ${ }^{10}$ Although she had not reported his (criminal) behaviour, the abuse created noise and other disturbance, and neighbours had complained (about this ASB). Practitioners were certainly conscious of the vulnerability of the resident. Nevertheless, this did not prevent them from serving her with a notice seeking possession of her property. Although this case centred on an adult offspring, the problem of 'parent abuse' is increasingly evident within the ASB agenda (Nixon and Hunter, 2009), and yet this is an issue that is poorly understood (Holt, 2009). As demonstrated in the case discussed here, it is also under-reported. Holt (2009) suggests that many parents choose not to report abusive children because their experiences may be conflicting, difficult to articulate and compounded by the notion of unconditional love. Certainly, the appropriateness of holding parents accountable for the behaviour of their children (old or young) in these circumstances has to be called into question, along with the use of ASB powers for dealing with the consequences of what is criminal behaviour.

\section{Were the interventions effective?}

In short, it is difficult to assess whether the case studies were effective, as there was little evidence of systematic evaluation: 12 out of 46 cases contained some evidence that systematic evaluation might have been conducted. Even so, most of these evaluations had limitations: little (and sometimes inappropriate) use of data; no statistical analysis; lack of control areas; and, little consideration of displacement or longer-term sustainability. None of this stopped claims of success for the cases - all but one were said to have been successful in stopping the problem or alleviating its impact. $^{11}$

\section{Discussion}

This article has drawn attention to how problems regarded by practitioners as antisocial are wide ranging, multifaceted and appear to be prioritised for action reactively. There is little evidence of systematic analysis of problems; a focus on enforcementtype interventions; and systematic evaluation of impact is rare or weak. The remainder of this article situates these findings within the development of ASB policy in England and Wales, and considers the implications for solving problems. Examination of the case studies showed that systematic analysis of problems was unusual. This reflects the findings of other studies that have demonstrated that, more broadly, analysis of crime problems for the purpose of crime prevention work is limited ( Read and Tilley, 2000 ; Bullock et al , 2006 ). Weaknesses are due, at least 
in part, to a lack of organisational commitment to developing analytic capacity. This section sets out other explanations for these weaknesses, specific to analysing and understanding ASB, together with some implications for practice.

Systematically analysing ASB presents difficulties. It is difficult to measure what is ill-defined (more on which shortly). The majority of incidents of ASB are unreported (Flatley et al, 2008). Under-reporting is shaped by a number of factors (Casey and Flint, 2007). Some incidents, such as young people congregating, may not be viewed as ASB; others are seen as too trivial to report; and members of the public may become resigned to persistent problems. The response of local agencies further influences reporting practice. It may not be clear how to report ASB, or people may believe that the authorities will not act and thus do not report incidents. Underreporting may also result from concerns about the consequences of doing so, such as fear of reprisals from perpetrators. Reflecting the diversity of ASB, when problems are reported, they are reported to a range of agencies, making it harder for analysts to collate data (Armitage, 2002).

Although there are inherent difficulties in analysing ASB, a further explanation for the lack of analysis shown in the case studies can be found in how ASB policy has developed in England and Wales. The message from central government has been that practitioners should act to tackle ASB using their new and extended enforcement powers. Collation and analysis of data has not been encouraged. Indeed, rather the reverse has been true. In developing its approach to tackling ASB, the Home Office decided not to centrally collate prevalence data from local areas (House of Commons, 2007) nor to encourage the collation of data at the local level.

The lack of commitment to the generation of prevalence data about ASB creates difficulties for crime prevention practice, which are becoming increasingly evident. There are no central data on trends of ASB that could be used to analyse local problems, make comparisons between areas, inform the development of strategies and tactics, identify priority areas, understand how powers and tools are being used and to evaluate outcomes (House of Commons, 2007; Prior, 2009). As Prior (2009, p.7) notes, "there is no "epidemiology" of ASB because no prevalence data are collected and analysed at a societal level'. Practitioners seeking to understand and prioritise ASB problems become reliant on local mechanisms for generating data. There is a wide range of ways that this might be done, including visual audits, analysis of ASB incidents reported to agencies, police recorded crime and incident data, analysis of CCTV footage, forms of community consultation and surveys of public views and perceptions (Harradine et al, 2004). However, there has been little central direction about how to do this. ${ }^{12}$ Evidence regarding the nature of ASB problems at the local level remains fragmentary (Prior, 2009).

The term ASB is vague and, as demonstrated by the range of behaviours targeted by the case studies, can draw in diverse criminal and non-criminal behaviours. The widely cited 1998 Crime and Disorder Act stresses that ASB comprises acts that cause (or may cause) harassment, alarm or distress. In developing their response to ASB, the UK government preferred not to enter into debates about which behaviours are anti-social. They have pursued the view that practitioners, and members of the public, have a 'common sense' understanding of what ASB is and recognise it when they see it (House of Commons, 2007). ASB has been defined as 'any activity that impacts on other people in a negative way, and the key to categorising behaviour as anti-social must be consideration of its impact on others' ${ }^{13}$ On this basis, it is important to consider people's 'subjectively mediated' understandings and experiences of ASB (Prior, 2009, p.10). 
Reflecting the view that understandings of ASB are subjectively mediated (and, more cynically, perhaps reflecting the above-mentioned difficulties in collating prevalence data), there has been interest in generating information about citizen's 'perceptions' of ASB. Perception data have become the principle source of evidence about ASB (Squires, 2006; Prior, 2009; Mackenzie et al, 2010). However, analysis of the case studies revealed little evidence of perception data being used to understand and prioritise problems. This is unlikely to reflect lack of data with which to do so. The British Crime Survey (BCS) collates information about perceptions of seven forms of ASB at a national level (see Flatley et al, 2008; Moon et al, 2009) and, at the time of writing, the Audit Commission in England and Wales requires that local authorities collect periodic ASB perception data. ${ }^{14}$ Even so, using these forms of data to help understand and solve problems locally is not straightforward. The resolution of the BCS is not such that it can be used to unpack and scrutinise ASB problems at the local level (Begum et al, 2009). The data collated by the Audit Commission could facilitate this, but these data are limited to one question about local perceptions of ASB. ${ }^{15}$ As with the BCS, certain categories of victims (the views of young people and businesses for example) are missed out altogether. It would seem that these data are collated primarily for the purposes of performance management rather than to help practitioners prioritise and understand problems.

That the term ASB is vague has further consequences for crime prevention practice. The current approach to defining ASB is almost limitless in scope, and it is not clear to practitioners which behaviours to monitor and attempt to address (Harradine et al, 2004). To complicate this, ASB is a 'contested concept' (Millie, 2009 , p.2). As such, it means different things to different people, and even within communities there is not likely to be agreement about what constitutes ASB (Jacobson et al, 2005). The open-ended and subjective nature of the ASB agenda thus raises questions about how problems are prioritised for preventative action. Analysis of the case studies showed that neither perception nor prevalence data are routinely used to determine local priorities. Instead, where it was apparent how a problem was identified, there was a focus on complaints. Complaints are, of course, one source of information about ASB problems. However, they are limited on their own. Using complaints as a mechanism to prioritise local action forces attention on the concerns of those who are most prepared to engage with the authorities. We have seen the reasons why ASB is under-reported, and there are thus good reasons to think more broadly about how to prioritise problems.

The problems being tackled by the case studies were diverse, and responses often multifaceted, but focus on enforcement interventions was evident. This is not surprising given that policy has concentrated on the development of enforcement interventions. The approach has been to stress the use of specific outputs in preference to the development of solutions to ASB problems. This was cemented by a performance management culture that sought to count numbers of Anti-Social Behaviour Orders (ASBOs) generated and arrests made (Hodgkinson and Tilley, 2007). As noted in the introduction, there has been much critical comment on this enforcement focus. I do not wish to repeat this critique save to note some implications for crime prevention.

Issues addressed in the name of ASB, as demonstrated in the case studies, are extremely diverse, and their causes and consequences varied. Sustainable solutions to ASB problems are unlikely to be found in enforcement interventions in many cases. Hodgkinson and Tilley (2007) note that the efficacy of enforcement measures, such as ASBOs, is rooted in the premise that ASB is the product of a small number of 
chronically badly behaved individuals who will respond to the pressure applied through such measures. They suggest that the available evidence does not support either of these assertions. Nor are sustainable solutions likely to be found in any one type of intervention. Instead, interventions need to be shaped by a more nuanced understanding of the nature of specific problems. Burney (2005, p.165) puts it well when she notes that "one label - "anti-social behaviour" - is used to cover any number of different troubles and annoyances which in reality require quite distinct and focused responses graded and tailored to the matter in hand, be it an aggressive alcoholic neighbour, a crowd of young people gathering outside a shop, a drugaddicted beggar, a flat used for prostitution or a vandalised playground'.

Comment on approaches to tackling ASB appears to have become somewhat polarised: supportive interventions versus the use of enforcement powers. Rather less has been made of techniques that seek to modify the immediate environment in which ASB problems occur. This was reflected, indeed, in the case studies where situational and environmental design techniques were rather little used. Given the broad nature of ASB problems, there would seem to be good reasons to think broadly and imaginatively about how to solve problems. Situational and environmental crime prevention techniques may be useful, particularly in cases where problems are location specific. This certainly incorporates problems classified here under the categories of misuse of space, youths hanging around, environmental problems and nuisance premises. ${ }^{16}$

Evaluations presented in the case studies were generally weak or nonexistent. Indeed, more broadly, there has been little investment in evaluating the impact of the new ASB interventions and powers, a point acknowledged by the Home Office (House of Commons, 2007). Practitioners have not been encouraged to systematically examine the outcomes of their interventions, and the weaknesses observed here are therefore hardly surprising. It is clear that practitioner evaluations of policing and crime reduction interventions are generally weak (Bullock et al, 2006; Knutsson, 2009 ; Bullock and Ekblom, 2010). Further, evaluation in this context is not straightforward: the abovementioned problems of defining and measuring ASB complicate evaluations. The measure of success has been taken to be the community's view on whether the problems have been stopped. ${ }^{17}$ At best, this seems to have been interpreted in terms of whether there have been more complaints. This is a problematic approach given what we know about the nature of reporting ASB.

All of the above represent challenges for the transfer of knowledge. As noted in the introduction, the case studies were not explicitly defined as a knowledge base, and yet the aim was clearly that practitioners could learn from the experiences of others and replicate good practice. A final question then is, 'Could practitioners use these case studies to select successful interventions'? It is clear that the evaluation of outcomes was extremely limited. Although the projects may have been successful, evidence was not provided to demonstrate it. As noted, we do not really know which interventions are effective in tackling ASB, and beyond this if interventions are successful what mechanisms bring about change. The evaluations contained in these case studies do little to inform this picture. ${ }^{18}$

\section{Conclusion}

Elizabeth Burney, in a book published in 2005, wonders whether the high status ascribed to tackling ASB may soon peak and be usurped by another social problem. Writing some 5 years later, there seems no sign of this. If anything, the ASB agenda continues to gain momentum within policy discourse, although enthusiasm for 
enforcement through the use of ASBOs may be waning. ${ }^{19}$ Running alongside the ASB agenda, though perhaps not explicitly linked, is the development and implementation of 'neighbourhood policing' throughout UK police services. At the time of writing, neighbourhood policing is conducted by dedicated police teams at the micro level and promises to focus policing around locally determined priorities. ${ }^{20}$ In practice, these priorities are likely to be low-level crime problems and ASB (Bullock, 2010). Understanding and tackling ASB continues to be important for policing and crime reduction practice.

This article has questioned the mechanisms for addressing ASB. Weaknesses evident can be explained, at least in part, by the dominant government discourse that has promoted enforcement interventions rather than the preventative process. The obvious conclusion is that a change in focus is required. In particular, a focus on problem solving through greater understanding of ASB problems, searching for wideranging responses to ASB and considering outcomes of interventions.

\section{Notes}

1 The Home Office Anti-Social Behaviour Unit (ASBU) was set up in January 2003 to set develop ASB policy, powers and interventions as well as to support local delivery. In 2004 the 'Together' campaign was launched followed by the 'Respect' campaign (Jacobson et al, 2005).

2 Relevant legislation since 1997 includes: Crime and Disorder Act (1998); The Police Reform Act (2002); Anti-Social Behaviour Act (2003); Clean Neighbourhoods and Environment Act (2005); Organised Crime and Police Act (2005); Emergency Workers Obstruction Act (2006); Police and Justice Act (2006); Violent Crime Reduction Act (2006); Housing and Regeneration Act (2008); Criminal Justice and Immigration Act (2008), as well as procedural and rule changes.

3 Available at http://webarchive.nationalarchives.gov.uk/20100405140447/, http://asb.homeoffice.gov.uk/members/article.aspx?id=75248482 (24 March 2010).

4 Available at http://webarchive.nationalarchives.gov.uk/20100405140447/, http://asb.homeoffice.gov.uk/members/article.aspx?id=75248482 (24 March 2010).

5 Occasionally 47 are referred to, as one large project was split into two to aid some analysis.

6 Available at http://webarchive.nationalarchives.gov.uk/20100405140447/asb.homeoffice.g ov.uk/members/case-studies/default.aspx?id=8482 (20 May 2010).

7 Although this information has been coded, quantified and classified for the purposes of presentation, the findings should be seen as indicative. Coding is not a precise science, the information available was sometimes limited and the categories used are not always mutually exclusive.

8 Available at http://webarchive.nationalarchives.gov.uk/20100405140447/, http://asb.homeoffice.gov.uk/members/case-studies/article $\cdot$ aspx $? \mathrm{id}=8722$ (20 May 2010).

9 Of course the issue of housing tenure was not always relevant to the problem and the response/s. In addition, the housing status of the perpetrator may not have been noted in the case study. 
10 Available at http://webarchive.nationalarchives.gov.uk/20100405140447/, http://asb.homeoffice.gov.uk/members/case-studies/article.aspx?id=11896 (20 May 2010).

11 The 'one' actually claimed that it was too soon to tell whether it had been successful rather than it had been unsuccessful.

12 Indeed, the Labour governments made available extensive Web-based guidance for practitioners in tackling ASB (follow the link at note 13). It is revealing that practically nothing has been made available about data, analysis or evaluation.

13 See http://webarchive.nationalarchives.gov.uk/20100405140447/asb.homeoffice.g ov.uk/members/article.aspx?id=7536 (20 May 2010).

14 www.audit-commission.gov.uk/localgov/audit/nis/pages/default.aspx (10 May 2010).

15 Following the BCS, this asks respondents to rate the extent to which the following are a problem: noisy neighbours or loud parties, teenagers hanging around the streets, rubbish or litter lying around, vandalism, graffiti and other deliberate damage to property or vehicles, people using or dealing drugs, people being drunk or rowdy in public places, abandoned or burntout cars.

16 See Hodgkinson and Tilley (2007) and Millie (2009) for some examples of situational approaches to tackling ASB.

17 See http://webarchive.nationalarchives.gov.uk/20100405140447/asb.homeoffice.g ov.uk/members/article.aspx?id=7534 (20 May 2010).

18 There are many other dimensions to transferring knowledge in the crime reduction field detailed consideration of which are beyond the scope of this article (see Bullock and Ekblom, 2010; Ekblom, 2011).

19 www.homeoffice.gov.uk/media-centre/speeches/beyond-the-asbo (3 August 2010).

20 See http://cfnp.npia.police.uk/8482 (24 March 2010).

\section{References}

Armitage, R. (2002) Tackling Anti-social Behaviour: What Really Works. London: Nacro, http://www.nacro.org.uk/data/fi les/nacro-2004120296-497.pdf, accessed 25 March 2010.

Ashworth, A., Gardner, J., Morgan, R., Smith, A. T. H., von Hirsch, A. and Wasik, M. (1998) Neighbouring on the oppressive: The government's 'anti-social behaviour order' proposals. Criminal Justice 16 (1): 7-14.

Begum, B., Johnson, S. and Ekblom, P. (2009) Anti-Social Behaviour: A Practitioners Guide. London: University College London.

Brown, A. (2004) Anti-social behaviour, crime control and social control. The Howard Journal 43 (2): 203-211.

Burney, E. (2005) Making People Behave: Anti-social Behaviour, Politics and Policy. Cullompton, UK: Willan.

Burney, E. (2009) Respect and the politics of behaviour. In: A. Millie (ed.) Securing Respect: Behavioural Expectations and Anti-Social Behaviour in the UK. Bristol, UK: The Policy Press. 
Bullock, K. (2010) Improving accessibility and accountability - Neighbourhood policing and the policing pledge. Safer Communities: International Journal of Community Safety 9 (1): 10-19.

Bullock, K. and Ekblom, P. (2010) Richness retrievability and reliability - Issues in a working knowledge base for good practice in crime prevention . European Journal on Criminal Policy and Research 1 (16): 29-47.

Bullock, K., Erol, R. and Tilley, N. (2006) Problem-Oriented Policing and Partnerships. Cullompton, UK: Willan.

Campbell, C. (2002) A Review of Anti-Social Behaviour Orders. London: Home Office. Home Office Research Study 236,

http://www.homeoffice.gov.uk/rds/pdfs2/hors236.pdf, accessed 20 May 2010.

Casey, R. and Flint, J. (2007) Active citizenship in the governance of anti-social behaviour in the UK: Exploring the non-reporting of incidents. People, Place \& Policy Online 1 (2): 69-79.

Cooper, C., Brown, G., Powell, H. and Sapsed, E. (2009) Exploration of Local Variations in the Use of Anti-social Behaviour Tools and Powers . London: Home Office. Home Office Research Report 21, http://www.homeoffice.gov.uk/rds/pdfs09/horr21c.pdf, accessed 20 May 2010.

Department for Children Schools Families (DCSF). (2008) Youth Task Force Action Plan. London: Department for Children, Schools and Families, http://www.dcsf.gov.uk/everychildmatters/Youth/youthmatters/youthtaskforce/action plan/actionplan/, accessed 2 April 2010.

Ekblom, P. (2011) Crime Prevention, Security and Community Safety using the 5Is Framework. Basingstoke, UK: Palgrave Macmillan, (in press).

Flatley, J., Moley, J. and Hoare, J (2008) Perceptions of Anti-social Behaviour Findings from the 2007/08 British Crime Survey. London: Home Office. Home Office Statistical Bulletin 15/08, http://www.homeoffice.gov.uk/rds/pdfs08/hosb1508.pdf, accessed 20 May 2010.

Harradine, S., Kodz, J., Lemetti, F. and Jones, B. (2004) Defining and Measuring Antisocial Behaviour. London: Home Office. Home Office Development and Practice Report 26, http://www.homeoffice.gov.uk/rds/pdfs04/dpr26.pdf, accessed 20 May 2010.

Hodgkinson, S. and Tilley, N. (2007) Policing anti-social behaviour: Constraints, dilemmas and opportunities. The Howard Journal 46 (4): 385-400.

Holt, A. (2009) Parent abuse: Some reflections on the adequacy of a youth justice response. Internet Journal of Criminology, http://www.internetjournalofcriminology.com/, accessed 20 May 2010.

House of Commons. (2007) House of Commons Committee of Public Accounts: Tackling Anti - Social Behaviour Forty-fourth Report of Session 2006 - 2007 .

London: The Stationary Office, http://www.parliament.the-

stationeryoffice.co.uk/pa/cm200607/cmselect/cmpubacc/246/246.pdf, accessed 20 May 2010.

Jacobson, J., Millie, A. and Hough, M. (2005) Tackling Anti-Social Behaviour: A Critical Review (ICPR Research Paper 2). London: Institute for Criminal Policy Research, King's College London. hdl.handle.net/234/3791, accessed 24 March 2010. Knutsson, J. (2009) Standard of evaluations in problem-oriented policing projects: Good enough? In: J. Knutsson and N. Tilley (eds.) Evaluating Crime Reduction Initiatives, Crime Prevention Studies, Vol. 24. Monsey, NY: Criminal Justice Press. 
Local Government Ombudsman (LGO). (2005) Special Report: Neighbour Nuisance and Anti-social Behaviour. London: LGO, http://www.lgo.org.uk/publications/specialreports/, accessed 20 May 2010.

Mackenzie, S., Bannister, J., Flint, P., Parr, S., Millie, D. and Fleetwood, J. (2010) The Drivers of Perceptions of Anti-Social Behaviour. London: Home Office. Research Report 34, http://rds.homeoffice.gov.uk/rds/pdfs10/horr34c.pdf. Millie, A. (2006) Anti-social behaviour: Concerns of minority and marginalised Londoners. Internet Journal of Criminology, http://www.internetjournalofcriminology.com, accessed 20 May 2010. Millie, A. (2009) Anti-social Behaviour. Maidenhead, UK: Open University Press. Millie, A., Jacobson, J., Hough, M. and Paraskevopoulou, A. (2005) Anti-social Behaviour in London: Setting the Context for the London Anti-Social Behaviour Strategy July 2005. London: Greater London Authority, https://dspace.lboro.ac.uk/dspace-jspui/handle/2134/95, accessed 20 May 2010.

Moon, D., Walker, A., Murphy, R., Flatley, J., Parfrement-Hopkins, J. and Hall, P. (2009) Perceptions of crime and anti-social behaviour: Findings from the 2008/09 British crime survey. Supplementary Vol. 1 to Crime in England and Wales 2008/09. Home Office Statistical Bulletin 17/9. London: Home Office, http://rds.homeoffice.gov.uk/rds/pdfs09/hosb1709.pdf, accessed 20 May 2010 .

National Audit Office (NAO). (2006) Tackling Anti-social Behaviour. London: The Stationery Office. Report by the Comptroller and Auditor General, HC 99 session 2006-2007, http://www.officialdocuments.gov.uk/document/hc0607/hc00/0099/0099.pdf, accessed 20 May 2010. Nixon, J. and Hunter, C. (2009) Disciplining women: Anti-social behaviour and the governance of conduct. In: A. Millie (ed.) Securing Respect: Behavioural Expectations and Anti-social Behaviour in the UK. Bristol, UK: The Policy Press. Prior, D. (2009) The 'problem' of anti-social behaviour and the policy knowledge base: Analysing the power/knowledge relationship. Critical Social Policy 29 (1): 523.

Read, T. and Tilley, N. (2000) Not Rocket Science? Problem-solving and Crime Reduction. London: Home Office. Crime Reduction Research Series Paper 6, http://rds.homeoffice.gov.uk/rds/prgpdfs/crrs06.pdf, accessed 1 June 2010.

Respect. (2006) Respect Action Plan. London: Respect, http://webarchive.nationalarchives.gov.uk/20100405140447/ http://asb.homeoffice.gov.uk/uploadedFiles/Members_site/Articles/About_Respect/re spect_action_plan.pdf, accessed 20 May 2010.

Squires, P. (2006) New labour and the politics of antisocial behaviour. Critical Social Policy 26 (1): 144-168.

Squires, P. and Stephen, D. (2005) Rethinking ASBOs. Critical Social Policy 25 (4): 517-528.

Youth Taskforce. (2008) Youth Taskforce Action Plan. London: Department for Children, Schools and Families, http://www.dcsf.gov.uk/everychildmatters/Youth/youthmatters/youthtaskforce/action plan/actionplan/, accessed 20 May 2010. 